\title{
Keragaman Gen NRAMP-1 dan INOS pada Ayam Sentul Seleksi
}

\author{
Polymorphism NRAMP-1 and INOS genes in Selected Sentul Chickens \\ M. Ardiyana ${ }^{1}$, C. Sumantri ${ }^{2}$, S.Murtini ${ }^{3}$, \& T. Sartika ${ }^{4}$ \\ ${ }^{1}$ Mahasiswa Pascasarjana Program Studi Ilmu Produksi dan Teknologi Peternakan, \\ Fakultas Peternakan, IPB \\ ${ }^{2}$ Departemen Ilmu Produksi dan Teknologi Peternakan, Fakultas Peternakan, IPB \\ ${ }^{3}$ Departemen Ilmu Penyakit Hewan dan Kesmavet, Fakultas Kedokteran Hewan, IPB \\ Jln. Agatis, Kampus IPB Dramaga, Bogor, 16680, Indonesia \\ ${ }^{4}$ Balai Penelitian Ternak, PO BOX 221-Bogor 16002, Indonesia \\ Email koresponden author: melatiardiyana@gmail.com
}

\begin{abstract}
NRAMP-1 protein and INOS enzyme have been shown as deffense mechanism against bacteria and virus infection. These genes have not been investigated in Sentul Selection chickens. This study was aimed to determine the polymorphism of NRAMP-1 and INOS in Sentul Selected chickens. A number of 172 sentul selected chickens was observed for NRAMP-1 and INOS genes using PCR-RFLP. The frequency of genotypes and alleles, polymorphic information content and Hardy-Weinberg equilibrium status (HWE) were analyzed. Polymorphism in NRAMP1|SacI and INOS|AluI were observed. The population was in HWE for both genes. NRAMP1 gene frequencies had higher TC genotypes and INOS gene frequencies had higher $\mathrm{CC}$ genotypes $(\mathbf{P}<\mathbf{0 . 0 5})$ in Selected Sentul chickens. Furthermore, the NRAMP1 and INOS genes, the frequency of allele $C$ was higher than the $T$ allele. It could be concluded that NRAMP-1 and INOS gene has potential to propose has associated with immune traits in Sentul chicken.
\end{abstract}

Keywords: INOS gene, NRAMP1 gene, polymorphism, Selected Sentul chickens

\section{PENDAHULUAN}

Ayam sentul termasuk ayam lokal Indonesia yang berasal dari Gallus gallus (ayam Hutan Merah), serta telah mengalami proses domestikasi di Indonesia. Nataamijaya (2000) mengemukakan bahwa di Indonesia terdapat 32 breed ayam lokal yang berbeda berdasarkan penampilan fenotipnya. Ayam SenSi-1 Sentul Terseleksi (Agrinak) merupakan salah satu galur murni (pure line) ayam lokal pedaging unggul, yang dapat dimanfaatkan sebagai ayam niaga (final stock) dan/atau sebagai ayam tetua (parent stock). Ayam ini telah ditetapkan sebagai galur ayam lokal pedaging asli Indonesia dengan SK Mentan Nomor 39/ Kpts/PK.020/1/2017, tanggal 20 Januari 2017, tentang Pelepasan Galur Ayam SenSi-1 Agrinak. Keunggulan dari ayam SenSi-1 Agrinak yaitu memiliki bobot hidup rata-rata lebih besar dari ayam kampung, pada umur 10 minggu untuk jantan $1066 \pm 62,5 \mathrm{~g}$ /ekor dan untuk betina $745 \pm 114$ g/ekor. Kriteria seleksi yang tidak dilakukan pada ayam betina, kecuali warna bulu bertujuan agar sifatsifat ketahanan tubuh ayam SenSi-1 Agrinak tidak banyak berubah dari ketahanan tubuh rumpunnya.

Konsumen menginginkan produk-produk pangan yang semakin bebas dari bahan-bahan kimia sehingga menuntut agar industri peternakan ayam semakin mengurangi penggunaan obat-obatan dalam menghadapi serangan penyakit. Hal inilah yang mendorong peneliti di bidang peternakan agar mencari cara-cara alternatif dalam menghadapi dan menanggulangi masalah penyakit pada ternak. Program pemulian dengan pendekatan genetik dapat dipilih dan diterapkan sebagai salah satu langkah untuk meningkatkan mutu genetik ternak. Metode seleksi terarah pada tingkat DNA dapat menyebabkan perubahan keragaman genetik dan frekuensi gen dari suatu populasi ternak (Togashi dan Lin 2010; Dai et al. 2017), sehingga sifat yang dikehendaki dapat ditingkatkan seperti ketahanan ternak terhadap serangan berbagai penyakit. Salah satunya adalah dengan metode seleksi genetika dengan pendekatan genetik molekuler. Gen yang berperan dalam gen sistem ketahanan penyakit banyak, diantaranya adalah gen NRAMP1 dan INOS.

Kedua gen tersebut (NRAMP-1 dan INOS) bekerja secara sinergi di dalam sel makrofag. Makrofag merupakan sel pada jaringan yang berasal dari sel darah putih yang disebut monosit (Abbas et al. 2017). Peran makrofag adalah untuk memfagositosis seluler dan patogen serta untuk menstimulasikan limfosit dan sel imun lainnya untuk merespon patogen. Reaksi tersebut selanjutnya akan menginduksi terjadinya respons imun spesifik yang diperantarai oleh sel $\mathrm{T}$ helper dan sel B untuk memproduksi 
antibodi spesifik. Adanya ekpresi gen NRAMP-1 dan INOS pada sel makrofag, akan memudahkan sel tersebut dalam menelan dan membunuh patogen atau bakteri yang berhasil menembus ke jaringan.

Gen NRAMP-1 dan INOS menunjukkan berasosiasi positif dengan ketahanan ayam terhadap Salmonella enteritidis (Lamont et al. 2002; Malek dan Lamont 2003; Tohidi et al. 2013). He et al. (2013) dalam penelitiannya melaporkan bahwa mutasi pada situs g.24101991 A>T gen NRAMP-1 berasosiasi signifikan dengan ketahanan ayam terhadap S. enteritidis. Ekspresi gen NRAMP-1 dan INOS yang tinggi ditemukan pada jaringan hati dan usus (He et al. 2013; Sundaresan et al. 2005). Karakterisasi terhadap penciri gen tersebut pada ayam lokal Indonesia diharapkan dapat merekomendasikan lokus-lokus molekular yang dapat dijadikan penanda genetik (marker assisted selection) untuk menyeleksi ayam yang memiliki ketahanan terhadap penyakit yang baik untuk meningkatkan produktivitas ayam lokal Indonesia, khususnya ayam sentul seleksi.

\section{MATERI DAN METODE}

\section{Waktu dan Tempat Penelitian}

Penelitian ini dilaksanakan pada bulan Februari 2018. Penelitian dilaksanakan di Laboraturium Genetika Molekuler Ternak, Fakultas Peternakan Institut Pertanian Bogor.

\section{Materi}

Ayam sentul seleksi berasal dari Balai Penelitian Ternak, Ciawi. Ayam dipelihara di Laboratorium Lapang Genetika Ternak Fakultas Peternakan IPB. Ternak yang akan digunakan sebagai hewan percobaan adalah ayam sentul seleksi unisex dewasa berumur 24 minggu sebanyak 172 ekor ayam.

\section{Prosedur}

\section{Ekstraksi DNA (Sambrook et al. 1989)}

DNA diekstraksi dimulai dengan pengambilan sampel darah. Sebanyak $1 \mathrm{~mL}$ sampel darah diambil dengan menggunakan spoit pada vena brachiais di bagian sayap, kemudian darah dimasukkan ke dalam tabung 1,5 $\mathrm{mL}$ yang telah diisi dengan serbuk Ethylenediaminetetraacetic (EDTA). Ekstraksi DNA dilakukan dengan menggunakan metode Sambrook et al. (1989).

\section{Amplifikasi Polymerase Chain Reaction (PCR)}

Amplifikasi DNA dilakukan pada total volume 15 $\mu \mathrm{L}$, terdiri atas $1 \mu \mathrm{L}$ DNA, $10,85 \mu \mathrm{L}$ DW, $0,3 \mu \mathrm{L}$ primer (Tabel 1), 0,05 $\mu \mathrm{L}$ Taq polymerase, 1,5 $\mu \mathrm{L}$ buffer, $0,3 \mu \mathrm{L}$ dNTP dan $1,00 \mu \mathrm{L} \mathrm{MgCl}_{2}$. Campuran pereaksi dimasukkan ke dalam tabung 1,5 $\mu \mathrm{L}$ untuk dihomogenkan, kemudian didistribusikan ke masing-masing tabung yang berisi sampel DNA dan selanjutnya dimasukkan ke dalam mesin PCR. Amplifikasi DNA berlangsung di dalam mesin PCR Applied Biosystems dengan kondisi suhu predenaturasi $95{ }^{\circ} \mathrm{C}$ selama 5 menit, 35 siklus untuk tahapan denaturasi pada suhu $95^{\circ} \mathrm{C}$ selama 10 detik, annealing pada suhu 60 ${ }^{\circ} \mathrm{C}$ selama 20 detik dan elongasi pada suhu $72{ }^{\circ} \mathrm{C}$ selama 30 detik, kemudian dilanjutkan dengan tahap elongasi akhir pada suhu $72{ }^{\circ} \mathrm{C}$ selama 5 menit dalam satu siklus.
Produk PCR dielektroforesis menggunakan gel agarosa $1,5 \%$. Primer yang digunakan untuk mengamplifikasi gen NRAMP-1 ekson 11 dan INOS intron 24 disajikan pada Tabel 1 yang mengacu pada Muhsinin et al. (2016).

Tabel 1. Primer gen NRAMP-1 dan INOS (Muhsinin et al. 2016)

\begin{tabular}{llll}
\hline Gen & No. Akses & Sekuen Primer & $\begin{array}{l}\text { Panjang } \\
\text { Amplikon }\end{array}$ \\
\hline NRAMP-1 & AY072001.1 & F: CAA TGA GAC & $421 \mathrm{bp}$ \\
& & GGTGTC TGT GG & \\
& & R: CCC AGA AGA \\
& & AAT CTC CCT GC \\
INOS & \multirow{3}{*}{ AF537190.1 } & F: CCA AGG ACT $449 \mathrm{bp}$ \\
& & TAC AGGTG TGG & \\
& & R: CCA GGA TGT \\
& & TTG GGC TGT TG \\
\hline
\end{tabular}

Keterangan: F: forward, R: reverse

\section{Restriction Fragment Length Polymorphism (RFLP)}

Metode RFLP digunakan untuk penentuan genotipe ayam. Produk amplifikasi dari gen NRAMP-1 dan INOS dipotong dengan menggunakan enzim restriksi. Enzim restriksi yang digunakan pada gen NRAMP-1 ekson 11 adalah SacI (GAGCT $\mid$ C), sedangkan gen INOS intron 24 dipotong dengan enzim AluI (AG|CT). Sebanyak $5 \mu \mathrm{L}$ produk PCR dipindahkan ke dalam tabung $0,5 \mathrm{~mL}$ yang ditambahkan $0,9 \mu \mathrm{L} \mathrm{DW}, 0,4 \mu \mathrm{L}$ enzim restriksi dan $0,7 \mu \mathrm{L}$ buffer. Campuran tersebut diinkubasikan pada suhu $37^{\circ} \mathrm{C}$ selama kurang lebih 16 jam (overnight).

\section{Elektroforesis produk PCR-RFLP}

Produk PCR-RFLP dielektroforesis menggunakan gel agarosa dengan konsentrasi 2\%. Elektroforesis produk PCR-RFLP gen NRAMP-1 ekson 11 dan INOS intron 24 menggunakan gel agarosa $2 \%$ yang dibuat dengan cara sebanyak 0,6 g serbuk agarosa dilarutkan dalam larutan 0,5 × TBE (Tris Borat EDTA) sebanyak $30 \mathrm{~mL}$ kemudian dipanaskan dalam microwave selama 5 menit, dikocok dengan magnetic stirrer, ditambahkan 2,5 $\mu \mathrm{L}$ EtBr, dan dicetak sehingga terbentuk sumur-sumur di dalam gel. Produk PCR-RFLP sebanyak $5 \mu \mathrm{L}$ dicampurkan dengan $1 \mu \mathrm{L}$ loading dye kemudian dimasukkan ke dalam sumur-sumur gel. Marker DNA 100 bp sebanyak $2 \mu \mathrm{L}$ dimasukkan ke dalam sumur paling kiri sebagai penanda. Gel dialiri listrik $100 \mathrm{~V}$ selama 30 menit. Setelah elektroforesis selesai, gel agarosa divisualisasi dengan menggunakan sinar ultraviolet di dalam mesin UV Transiluminator.

\section{Analisis Data}

Genotipe yang diperoleh dari PCR-RFLP, kemudian dihitung nilai frekuensi alel, frekuensi genotipe, nilai keseimbangan Hardy-Weinberg, heterozigositas pengamatan, dan heterozigositas harapan berdasarkan rumus berikut:

\section{Frekuensi alel (Nei 1987) :}

$$
\mathrm{X} i=\frac{\left(2 n i i+\sum_{j \neq 1} n i j\right)}{(2 N)}
$$




\section{Keterangan :}

$\mathrm{Xi} \quad=$ frekuensi alel ke-i;

Nii $\quad=$ jumlah individu bergenotipe ii;

$\mathrm{Nij} \quad=$ jumlah individu bergenotipe $\mathrm{ij}$; dan

$\mathrm{N}=$ total sampel.

2. Frekuensi genotipe (Nei 1987) :

$$
\mathrm{X}_{1 i}=\frac{\sum_{i=1}^{n} n i}{(N)}
$$

\section{Keterangan :}

Xii $\quad=$ frekuensi genotype ke-i;

$\mathrm{Ni} \quad=$ jumlah individu bergenotipe ii; dan

$\mathrm{N} \quad=$ total sampel.

3. Keseimbangan Hardy-Weinberg (H-W) (Hartl dan Clark 1997) :

$$
\mathrm{X}^{2}=\sum \frac{(0-\mathrm{E})^{2}}{\mathrm{E}}
$$

\section{Keterangan :}

$\mathrm{X}^{2} \quad=$ nilai chi-square;

$\mathrm{O} \quad=$ jumlah genotipe teramati; dan

$\mathrm{E} \quad=$ jumlah genotipe harapan.

4. Heterozigositas (Nei 1987) :

$$
\text { Ho }=\sum_{i \neq j} \frac{N_{1 j k}}{N} \quad \mathrm{He}=1-\sum_{i=1}^{n} P_{1 i}{ }^{2}
$$

\section{Keterangan :}

Ho = heterozigositas pengamatan;

$\mathrm{N}_{\mathrm{ijk}} \quad=$ jumlah individu heterozigot pada lokus ke-1;

$\mathrm{N}^{\mathrm{ijk}} \quad=$ jumlah individu yang diamati;

$\mathrm{He} \quad=$ Heterozigositas harapan; dan

$\mathrm{P}_{1 \mathrm{i}} \quad=$ frekuensi alel ke-1.

\section{HASIL DAN PEMBAHASAN}

\section{Karakteristik Gen NRAMP-1 dan INOS}

\section{Amplifikasi Gen NRAMP-1 dan INOS pada Ayam Sentul Seleksi}

Fragmen gen NRAMP1 ekson 11 dan INOS intron 24 pada ayam Sentul Seleksi sebanyak 172 ekor telah diamplifikasi dengan menghasilkan panjang produk PCR masing-masing sebesar 421 bp dan 449 bp (Gambar 1). Kedua fragmen gen tersebut diamplifikasi pada suhu annealing $60{ }^{\circ} \mathrm{C}$ selama 20 detik dengan menggunakan
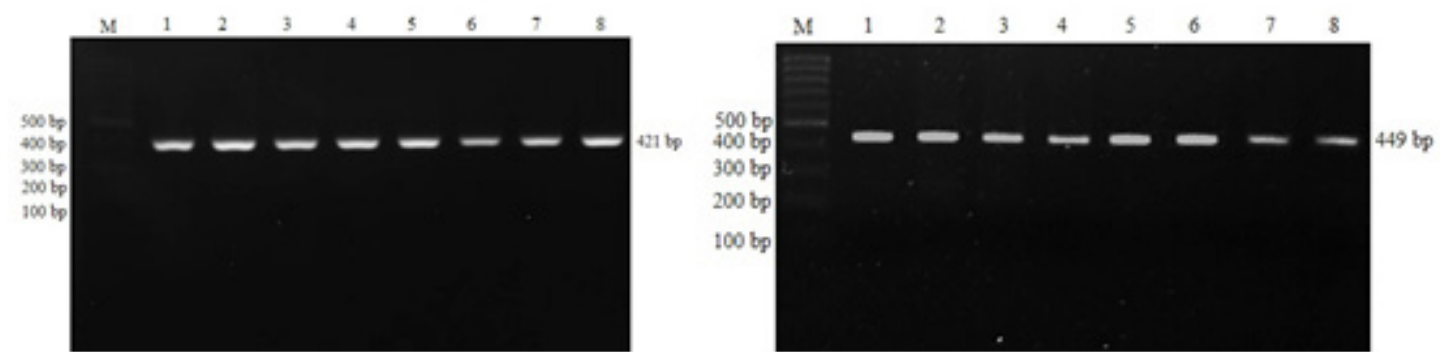

Gambar 1. Hasil amplifikasi gen NRAMP1 ekson 11 dan INOS intron 24 pada Sentul Seleksi. $\mathrm{M}=$ marker DNA $100 \mathrm{bp}$ mesin Thermocycler Esco. Hal ini sesuai dengan penelitian Muhsinin et al. (2016), tetapi berbeda dengan penelitian Liu et al. (2003) dan Ramasamy et al. (2011) pada suhu annealing yang telah dilakukan untuk primer fragmen gen NRAMP-1 ekson 11 dan INOS intron 24 yaitu masingmasing pada suhu $64{ }^{\circ} \mathrm{C}$ selama 90 detik dan $55^{\circ} \mathrm{C}$ selama 1 menit. Suhu annealing pada kedua gen tersebut berbeda karena disebabkan oleh perbedaan kondisi mesin PCR dan campuran pereaksi PCR.

\section{Identifikasi Genotipe Fragmen Gen NRAMP-1 dan INOS} Fragmen gen NRAMP-1 pada ekson 11 dan gen INOS intron 24 yang dianalisis RFLP dengan enzim restriksi AluI diperoleh tiga macam fragmen. Fragmen yang tidak terpotong oleh enzim $\mathrm{SacI}$ (421 bp) adalah genotipe TT, fragmen terpotong ( $258 \mathrm{bp}$ dan $163 \mathrm{bp}$ ) adalah genotipe CC, dan fragmen gabungan (421 bp, $258 \mathrm{bp}$, dan $163 \mathrm{bp}$ ) atau heterozigot adalah genotipe TC. Fragmen gen INOS yang terpotong oleh enzim AluI, ditunjukkan pada genotipe TT (449 bp), CC (310 bp dan 139 bp), dan genotipe heterozigot TC (449 bp, 310 bp, dan 139 bp) (Gambar 2).

\section{Frekuensi Genotipe dan Alel Fragmen Gen NRAMP-1 dan INOS}

Hasil analisis frekuensi genotipe dan frekuensi alel fragmen gen NRAMP-1|SacI ekson 11 gen INOS intron 24 pada ayam Sentul Seleksi disajikan pada Tabel 2. Proporsi genotipe pada ayam Sentul Seleksi yang diteliti menunjukkan bahwa frekuensi genotipe CC paling tinggi dibandingkan genotipe TC dan TT pada gen NRAMP1, tetapi berbeda dengan INOS karena genotipe TC paling tinggi dibandingkan TT dan CC. Hal tersebut menyebabkan tingginya frekuensi alel C pada ayam Sentul Seleksi.

Hasil penelitian ini menunjukkan bahwa fragmen gen NRAMP-1|SacI ekson 11 dan INOS|AluI intron 24 pada pada ayam Sentul Seleksi bersifat polimorfik karena terdapat tiga tipe genotipe yang ditemukan pada masingmasing fragmen gen tersebut dan frekuensi alel yang diperoleh lebih dari 0,01 (Nei dan Kumar 2000; Allendroft et al. 2013). Hasil penelitian Muhsinin et al. (2016) dan Tohidi et al. (2013) menunjukkan bahwa frekuensi genotipe CC gen NRAMP-1 memiliki frekuensi tinggi dan genotipe TT ditemukan rendah pada kedua ayam tersebut. Pada fragmen gen INOS intron 24 ditemukan frekuensi genotipe TC lebih tinggi. Hal ini berbeda dengan yang ditemukan pada ayam Barnevelder dan Broiler (Kramer et al. 2003) serta Muhsinin et al. (2016) pada ayam lokal Indonesia.

Frekuensi alel $\mathrm{C}$ tinggi pada semua populasi ayam Sentul Seleksi diduga akibat seleksi dan manajemen 

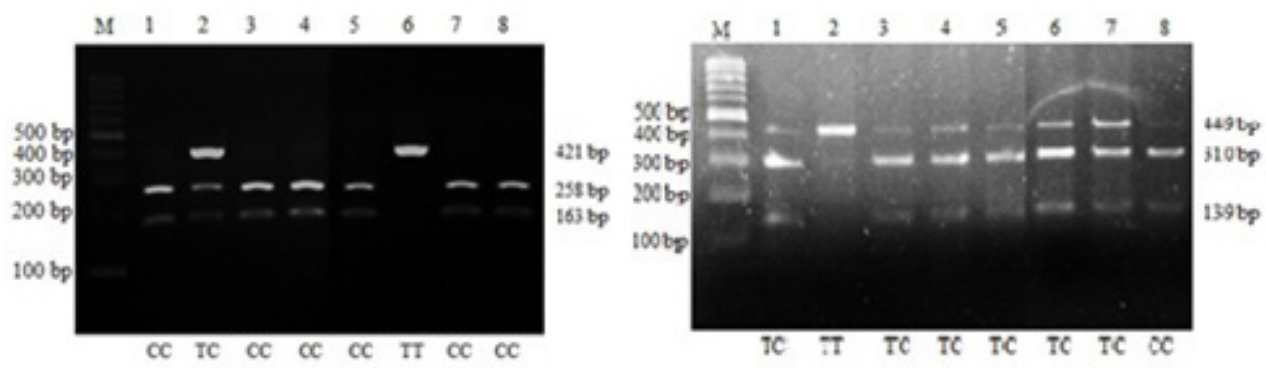

Gambar 2. Hasil PCR-RFLP fragmen gen NRAMP-1 ekson 11 dengan enzim restriksi SacI dan gen INOS intron 24 dengan enzim restriksi AluI pada gel agarosa 2\%. M= marker DNA 100 bp

Tabel 2. Frekuensi genotipe dan alel fragmen gen NRAMP-1 dan INOS pada populasi ayam Sentul Seleksi

\begin{tabular}{llccccc}
\hline \multirow{2}{*}{ Gen } & $\mathrm{N}$ & \multicolumn{3}{c}{ Frekuensi Genotipe } & \multicolumn{2}{c}{ Frekuensi Alel } \\
\cline { 3 - 7 } & & $\mathrm{TT}$ & $\mathrm{TC}$ & $\mathrm{CC}$ & $\mathrm{T}$ & $\mathrm{C}$ \\
\hline NRAMP-1 & 172 & $0,023(4)$ & $0,238(41)$ & $0,738(127)$ & 0,142 & 0,858 \\
\multirow{2}{*}{ INOS } & 172 & $0,070(12)$ & $0,733(133)$ & $0,157(27)$ & 0,456 & 0,544 \\
\hline
\end{tabular}

Keterangan: N: total populasi

perkawinan. Seleksi yang dilakukan peternak yaitu mempertahankan ayam-ayam yang memilki alel $\mathrm{C}$ dibandingkan dengan ayam-ayam yang memiliki alel $\mathrm{T}$. Menurut Noor (2010), faktor-faktor yang mempengaruhi frekuensi gen adalah seleksi, mutasi, pencampuran populasi, silang dalam, silang luar, dan genetic drift.

Gen NRAMP-1 dan INOS pada populasi ayam sentul seleksi bersifat polimorfik. Frekuensi genotipe tertinggi pada gen NRAMP-1 dan INOS masing-masing adalah CC dan TC. Kombinasi gen NRAMP-1 dan INOS disajikan pada Tabel 3. Frekuensi genotipe tertinggi pada kombinasi kedua gen tersebut adalah genotipe CCTC. Frekuensi genotipe terendah pada kombinasi kedua gen tersebut adalah genotipe TTTC, TTCC, TCCC, dan CCTT. Frekuensi genotipe kombinasi gen NRAMP-1 dan INOS pada ayam Sentul Seleksi disajikan pada Tabel 4.

Tabel 3. Genotipe kombinasi gen NRAMP-1 dan INOS pada ayam Sentul Seleksi

\begin{tabular}{lllll}
\hline Genotipe & & \multicolumn{3}{l}{ Gen INOS } \\
\cline { 3 - 5 } & & TT & TC & CC \\
\hline Gen & TT & TTTT & TTTC & TTCC \\
NRAMP-1 & TC & TCTT & TCTC & TCCC \\
& CC & CCTT & CCTC & CCCC \\
\hline
\end{tabular}

Tabel 4. Frekuensi genotipe kombinasi gen NRAMP-1 dan INOS pada ayam Sentul Seleksi

\begin{tabular}{lllll}
\hline Genotipe & & \multicolumn{3}{c}{ Gen INOS } \\
\cline { 3 - 5 } & & TT & TC & CC \\
\hline Gen & TT & 0,023 & 0,000 & 0,000 \\
NRAMP-1 & & $(\mathrm{n}=4)$ & $(\mathrm{n}=0)$ & $(\mathrm{n}=0)$ \\
& TC & 0,047 & 0,192 & 0,000 \\
& & $(\mathrm{n}=8)$ & $(\mathrm{n}=33)$ & $(\mathrm{n}=0)$ \\
& CC & 0,000 & 0,581 & 0,157 \\
& & $(\mathrm{n}=0)$ & $(\mathrm{n}=100)$ & $(\mathrm{n}=27)$ \\
\hline
\end{tabular}

\section{Derajat Keseimbangan Hardy-Weinberg, Heterozigositas, dan Polymorphic Informative Content (PIC)}

Hasil uji chi-square $(\chi 2)$ nilai heterozigositas pengamatan (Ho), nilai heterozigositas harapan (He), dan nilai Polymorphic Informative Content (PIC) menunjukkan bahwa frekuensi genotipe fragmen gen NRAMP-1|SacI ekson 11 berada dalam keseimbangan Hardy-Weinberg pada ayam Sentul Seleksi (Tabel 5). Fragmen gen INOS $\mid A l u$ I intron 24 (Tabel 5), nilai $\chi 2$ menunjukkan frekuensi genotipe menyimpang dari keseimbangan Hardy-Weinberg pada populasi ayam Sentul Seleksi. Menurut Allendorf et al. (2013), suatu populasi ternak dinyatakan berada dalam keseimbangan apabila frekuensi genotipe dan frekuensi alelnya konstan dari generasi ke generasi yang diakibatkan oleh penggabungan gamet yang terjadi secara acak dalam populasi yang besar. Populasi yang cukup besar tidak akan berubah dari satu generasi ke generasi lainnya jika tidak ada seleksi, migrasi, mutasi, dan genetic drift (Noor 2010).

Nilai heterozigositas merupakan rataan persentase lokus heterozigot tiap individu atau rataan persentase individu heterozigot dalam populasi (Nei dan Kumar 2000). Nilai heterozigositas pengamatan (Ho) pada ayam Sentul Seleksi yang dianalisis adalah 0,238 pada NRAMP-1|SacI dan 0,773 pada INOS $\mid$ AluI. Nilai heterozigositas harapan (He) pada ayam Sentul Seleksi yang dianalisis adalah 0,244 pada NRAMP-1 $\mid$ SacI dan 0.496 pada INOS $\mid$ AluI. Pada lokus NRAMP-1|SacI ekson 11 ditemukan nilai Ho lebih rendah daripada INOS $\mid$ AluI. Perbedaan yang besar antara nilai Ho dan He dapat dijadikan sebagai indikator adanya ketidakseimbangan genotipe pada populasi yang dianalisis. Hal ini dapat dijadikan indikasi adanya derajat endogami (perkawinan dalam kelompok) sebagai akibat dari proses seleksi yang intensif (Machado et al. 2003).

Nilai PIC merupakan indeks ideal untuk mengukur polimorfisme fragmen alel. Menurut Botstein et al. (1980), apabila nilai $\mathrm{PIC} \geq 0,50$ menunjukkan lokus yang sangat 
informatif, nilai PIC $0,25<$ PIC $<0,50$ menunjukkan lokus yang cukup informatif, dan nilai $\mathrm{PIC} \leq 0,25$ menunjukkan lokus memiliki informatif rendah. Berdasarkan pernyataan tersebut maka nilai PIC gen NRAMP-1|SacI ekson 11 termasuk kategori cukup informatif. Adapun nilai PIC gen INOS $\mid$ AluI intron 24 termasuk kategori sangat informatif.

Tabel 5. Hasil uji chi-square $(\chi 2)$, Heterozigositas, dan Polymorphic Informative Content (PIC) gen NRAMP-1 dan INOS pada ayam Sentul Seleksi

\begin{tabular}{lcccc}
\hline \multicolumn{1}{c}{ Gen } & $\chi 2$ & He & Ho & PIC \\
\hline NRAMP-1 & $0,101 \mathrm{~ns}$ & 0,244 & 0,238 & 0,460 \\
INOS & 53,634 & 0,496 & 0,773 & 0,956 \\
\hline
\end{tabular}

Keterangan: $\chi 2$ : Chi square $(\alpha 5 \%=3,841),{ }^{*}$ : nyata $(\chi 2$ hitung $>\chi 2$ tabel) Ho: Heterozigositas pengamatan, He: Heterozigositas harapan, PIC: Polymorphic Informative Content

\section{KESIMPULAN}

Gen NRAMP-1 dan INOS pada populasi ayam sentul seleksi bersifat polimorfik. Frekuensi genotipe tertinggi pada gen NRAMP-1 dan INOS masing-masing adalah CC dan TC. Frekuensi gen NRAMP-1 dan INOS berada dalam keseimbangan Hardy-Weinberg. Gen NRAMP-1 dan INOS memiliki potensi untuk dapat diasoasiasikan dengan sifat imunitas pada ayam Sentul terseleksi.

\section{DAFTAR PUSTAKA}

Abbas, A. K., A. H. Lichtman, \& S. Pilai. 2017. Molecular and cellular immunology. 9th ed. Philadelphia (US): Elsevier.

Allendorf, F. W., G. Luikar, S. N. Aitken. 2013. Conservation and the genetics of population. 2nd ed. Oxford (UK): Wiley-Blackwell.

Bauler, T. J., T. Starr, T. A. Nagy, S. Sridhar, D. Scott, C. W. Winkler, O. Steele-Mortimer, C. S. Detweiler, \& K. E. Peterson. 2017. Salmonella Meningitis Associated with Monocyte Infiltration in Mice. Am J Pathol. 187(1):187-199.

Botstein, D., R. L. White, M. Skolnick, \& R. W. Davis. 1980. Construction of genetic linkage map in human using restriction fragmen length polymorphisms. Amer J Hum. Genet. 32: 314-331.

Dai, C. H., J. Y. Wu, C. X. Zhao, L. H. Yu, W. B. Bao, \& S. L. Wu. 2017. Nramp1 gene expression in different tissues of Meishan piglets from newborn to weaning. Genet Mol Res. 16(1):1-10.

He, X. M., M. X. Fang, Z. T. Zhang, Y. S. Hu, X. Z. Jia, D. L. He, S. D. Liang, Q. H. Nie, \& X. Q. Zhang. 2013. Characterization of chicken natural resistanceassociated macrophage proteinencoding genes (NRAMP1 and NRAMP2) and association with salmonellosis resistance. Genet Mol Res. 12(1):618630.

Lamont, S. J., M. G. Kaiser, \& W. Liu. 2002. Candidate genes for resistance to Salmonella enteritidis colonization in chickens as detected in a novel genetic cross. Vet Immunol Immunopathol. 87(3-4):423-428.

Kramer, J., M. Malek, \& S. J. Lamont. 2003. Association of twelve candidate gene polymorphisms and response to challenge with Salmonella enteritidis in poultry. Anim Genet. 34(5):339-348.

Liu, W., M. Kaiser, \& S. J. Lamont. 2003. Natural resistanceassociated macrophage protein 1 gene polymorphisms and response to vaccine against or challenge with Salmonella enteritidis in young chicks. Poult Sci. 82:259-266.

Machado, M. A., I. Schuster, M. L. Martinez, \& A. L. Campos. 2003. Genetic diversity of four cattle breed using microsatellite markers. Rev Bras De Zool. 32: 93-98.

Malek, M., S. J. Lamont. 2003. Association of INOS, TRAIL, TGF-b2, TGF-b3, and IgL genes with response to Salmonella enteritidis in poultry. Genet Sel Evol. 1:99-111.

Muhsinin, M., N. Ulupi, A. Gunawan, I. W. T. Wibawan, \& C. Sumantri. 2016. Association of NRAMP1 polymorphisms with immune traits in Indonesian native chickens. Int J Poult Sci. 15: 401-406.

Nataamijaya, A. G. 2000. The native of chiken of Indonesia. Bull Plasma Nutfah. 6(1): 1-6.

Nei, M., S. Kumar. 2000. Molecular Evolution and Phylogenetics. New York (US): Oxford University Press.

Noor, J. 2010. Metodologi Penelitian Skripsi, Tesis, Disertasi dan Karya Ilmiah. Jakarta: Kencana Prenada Media Group.

Ramasamy, K. T., M. R. Reddy, \& S. Murugesan. 2011. Toll-like receptor mRNA expression, INOS gene polymorphism and serum nitric oxide levels in indigenous chickens. Vet Res Commun. 35: 321-327.

Sambrook, J., E. F. Fritsch, \& T. Maniatis. 1989. Moleculer Cloning: A Laboratory Manual. New York (USA): Cold Spring Harbour Lab Pr.

Sundaresan, N. R., K. A. Ahmed, V. K. Saxena, K. V. Sastry, M. Saxena, A. B. Pramod, M. Nath, K. B. Singh, T. J. Rasool, A. K. DevRoy, \& R. V. Singh. 2005. Differential expression of inducible nitric oxide synthase and cytokine mRNA in chicken lines divergent for cutaneous hypersensitivity response. Vet Immunol Immunopathol. 108(3-4): 373-385.

Tohidi, R., I. Idris, J. M. Panandam, \& M. H. Bejo. 2012. The effects of polymorphisms in IL- 2, IFN- $\gamma$, TGF- $\beta 2$, IgL, TLR-4, MD-2, and iNOS genes on resistance to Salmonella Enteritidis in indigenous chickens. Avian Pathol. 41: 605-612.

Tohidi, R., I. B. Idris, J. M. Panandam, \& M. H. Bejo. 2013. The effects of polymorphisms in 7 candidate genes on resistance to Salmonella Enteritidis in native chickens. Poult Sci. 92(4): 900-909. 